\title{
Coming to America: Can Nordic brand values engage American stakeholders?
}

Received (in revised form): 15th April, 2008

\begin{abstract}
JAMES RUBIN
is Assistant Professor of Business Administration at the Darden Graduate School of Business at the University of Virginia. He teaches, among other things, corporate communication and media, entertainment and sports management. He has written mainly in the genre of case study, recently on cases focusing on corporate branding and CSR. He has published, with Mary Jo Hatch, on the intersection of literary theory and corporate branding. His affiliations include the Arthur Page Society, the Conference for Corporate Communication and the Corporate Communication Institute. He wrote his dissertation at the University of Virginia on aristocrats, criminals and merchants as exemplary figures in the 18th century.
\end{abstract}

\section{MAJKEN SCHULTZ}

is Professor of Management at Copenhagen Business School and partner in the Reputation Institute. She is co-editor of Corporate Branding: Purpose, People, Process (with Yun Mi Antorini and Fabian Csaba, Copenhagen Business School Press, 2005) and the author of On Studying Organizational Cultures: Diagnosis and Understanding (De Gruyter, 1995). Her articles on corporate branding, organisational culture, identity and reputation management appear in Harvard Business Review, California Management Review, Corporate Reputation Review, European Journal of Marketing, Human Relations, Academy of Management Review, Academy of Management Journal, Journal of Management Inquiry and Organization Studies. Together, Hatch and Schultz have edited two books of potential interest to readers of this one: The Expressive Organization: Linking Identity, Reputation and the Corporate Brand (with Mogens Holten Larsen, Oxford University Press, 2000) and Organizational Identity:A Reader (Oxford University Press, 2004). Their most recent book Taking Brand Initiative: How Companies can Align Strategy, Culture and Identity through Corporate Branding was published by Jossey-Bass in 2008.

\section{MARY JO HATCH}

is Adjunct and Visiting Professor at the Copenhagen Business School and Professor Emerita at the University of Virginia. She is the author of Organization Theory: Modern, Symbolic and Postmodern Perspectives, now in its second edition (with Ann Cunliffe, Oxford University Press, 2006), and The Three Faces of Leadership: Manager, Artist, Priest (with Monika Kostera and Andrzej Kozminski, Blackwell, 2005). Her articles on corporate branding, organisational culture and organisational identity appear in Harvard Business Review, California Management Review, European Journal of Marketing, Journal of Brand Management, Human Relations, Academy of Management Review, Administrative Science Quarterly and Organization Studies.

\section{Keywords}

corporate brand; nordic brand; corporate social responsibility; stakeholder theory; global business, business ethics (vs Pharmaceutical Industry)

James Rubin

University of Virginia,

Darden Graduate School

of Business Administration,

100 Darden Blvd.

Charlottesville,VA 22903, USA

E-mail: RUBINJ@Darden.virginia. edu

\section{Abstract}

In this paper, we discuss the intersection of business strategy and proactive, self-reflective corporate branding in the Danish pharmaceutical company Novo Nordisk. With headquarters in Denmark, Novo Nordisk has 23,600 employees in 79 countries. The company has a leading market position in Europe, key segments in the United States, and strong positions in Asia. Still, the highly, even hyper-competitive, US market remains crucial even for a smaller, more specialised company like Novo Nordisk. American pharmaceuticals are now polling at all time lows in terms of public trust (if we leave out for the moment the exceptional example of Johnson \& Johnson (J\&J)), and there is a looming healthcare crisis of Type 2 diabetes in the United States as well as parts of the developing world. Can a company that announces 'growth-but not at any cost' sustain growth in North America? The question for Novo Nordisk in this market becomes whether there is room for a socially and environmentally responsible pharmaceutical brand that 'does the right thing' to differentiate itself from competitors. One of the most respected and recognised of 
Scandinavian corporations, will Novo Nordisk's brand values, so consistent with northern European culture, be 'lost in translation' by North American stakeholders even while the ways in which global companies come to define and act on brand values and meaning may well determine the future of Anglo-American business thinking? To address these questions, we draw on a multi-year project involving two case studies with the Danish company. Focusing on issues raised by the relationship between Novo Nordisk's brand strategy in Denmark and its North American subsidiary, we discuss Novo Nordisk's reaffirmation of its core identity in terms of continuity with its rich heritage in the care of diabetes and its brand platform of 'changing diabetes'. Charlotte Ersboll, the company's Vice President of Corporate Branding, explains that 'changing diabetes' emphasises the continuous fight against diabetes and how Novo Nordisk is demonstrating leadership in this fight through action. Novo Nordisk makes for a particularly timely example. We explicitly try to capture the difference, or at times dissonance, between stakeholder relationships in Nordic brands and in the United States. As a logical extension of Danish values, particularly their emphasis on employees and community, the company made extensive investments in a process of internal discovery that was originally conceived of as aligning corporate culture, internal brand identity and external branding. In fact, this process also led to a more expansive and richer concept of the brand with greater potential for alignment with internal and external stakeholders. The strategic trajectory from identity and values to connecting with all stakeholders through a brand has become more sophisticated and is gaining wider acceptance with managers. Yet it is a step many companies avoid to their ultimate cost. This study of Novo Nordisk originates with the Corporate Brand Initiative based at Copenhagen Business School. While the findings of case studies are still unfolding, Novo Nordisk suggests that successful corporate branding is closely tied to corporate culture; corporate branding is cross-functional; corporate branding may be mandated by top management, yet to succeed, executives at the top of a global brand must remain open to creative ideas from global subsidiaries; investment in a brand should be seen as a long-term strategy.

Journal of Brand Management (2008) 16, 30-39. doi:10.1057/bm.2008.17; published online 13 June 2008;

\section{A DIFFERENT KIND OF PHARMACEUTICAL}

Subsequent to its founders' receiving permission to manufacture insulin in Denmark, Novo Nordisk for many years was the only firm to manufacture both medical devices and insulin. ${ }^{1-5}$ In North America, the overall needle market has been split between device makers such as market leader Becton Dickinson (BD), the rebranded Coviden (formerly part of Tyco) and smaller companies like Terumo on the device side. Novo Nordisk has just over half the market share of the global insulin market. In the United States, Novo Nordisk's main competitor in the manufacture of insulin is Eli Lilly (15.6 billion in overall sales). Novo Nordisk invented the world's first insulin pen in 1985 and its Flexpen ${ }^{\circledR}$ is the leading insulin-delivery device in the United States. More recently, Novartis has combined manufacturing delivery devices for insulin as well as drugs.

The US healthcare market, since it is largely privatised, has particular structural features. Because medical device sales in general are 'business to business', a 
company such as $\mathrm{BD}$, for example, saw no need for corporate branding to connect with wider audiences. As is often the case, rebranding took place after the company was embroiled in a crisis in 1998, a drawnout class-action lawsuit. ${ }^{6}$ Given Novo Nordisk's wish to establish a global brand, another relevant feature in the United States is the aggressive and controversial marketing of brand name or 'blockbuster' drugs. This arguably makes large pharmaceuticals for some stakeholders less well known than a given product brand. They become 'endorsed identities' like diversified corporations such as Proctor and Gamble or Unilever. ${ }^{7,8}$ Consumers, for example, very likely did not connect Vioxx with Merck until it made the front pages of national newspapers when the product was recalled. Merck's recent settlement for \$US4.85bn in November 2007, however, suggests the importance to Merck of putting this damaging issue behind them for the sake of the corporate brand.

Novo Nordisk's reputation in Denmark and Scandinavia is unquestionable, as its continuing recognition worldwide for innovation in the specialised worlds of diabetes care and the treatment of hemophilia. It consistently appears in mostadmired polls in Denmark, and was first included in the Dow Jones Sustainability Index in 2001. Our discussion is framed, however, not so much by the problem of uniting a global corporate culture, in which Novo Nordisk has been remarkably successful through the 'Novo Way of Management' or 'Novo Way'. Rather, it is the larger and specific cultural competitive contexts in which it operates. If an American asks a Danish manager why a pharmaceutical company publishes a triple bottom line (TBL) report or is committed to social responsibility and the environment, the manager will most likely pause to make sure he or she heard you correctly, and then explain that these values express what the company stands for; it is a part of 'who they are' and is simply the 'right thing to do.' For Scandinavians, this is selfevident. If an American manager of one of the growing number of companies that publish a TBL or 'green bottom-line' report in the United States is asked the same question they will most likely start with the 'business case' for the idea, very likely adding that it is the 'right thing to do', and possibly saying it expresses core corporate values or 'who we are'. Novo Nordisk executives in Princeton, New Jersey, will begin as would a manager in Copenhagen, but add the 'business case', as well. This is, of course, anecdotal. Still, publishing a separate corporate social responsibility (CSR) report, for example, remains a fairly new thing in the United States (UPS, eg, a company early to the party in the United States, published its first 'corporate sustainability report' in 2002). Representing 'intangible assets' has not been explicitly rewarded by Wall Street, although some indices point in that direction. ${ }^{9}$ As accountants come to grips with the TBL phenomenon, it remains in most cases difficult to see where compliance ends and 'beyond compliance' begins. Adventurous US corporations may publish a separate CSR report. For Novo Nordisk, the TBL of 'financial, social and environmental' performance is the annual report.

In an industry dominated by very large corporations, Novo Nordisk (DKK 38,743 in 2006) is a niche player with a focused brand. US-based corporations, moreover, answer to a differently weighted, more 'market-driven' set of stakeholders, both in terms of share price and product price. Stakeholder theory may be more and more a practice as well as a theory, but in the only Western democracy without universal healthcare of some sort, and with 
recent healthcare legislation handing out largesse to pharmaceutical corporations, it is hard not to think that investors ultimately trump other stakeholders. In contrast, while Novo Nordisk demerged its detergent business (Novo Enzymes) for structural reasons, an added benefit was separating healthcare from the perception of the environmental risks associated with household product manufacturing such as detergents, even though enzymes found in Novo Nordisk products are in fact biodegradable. In the United States, biotech's like Genzyme or Genentec are seen as separate from big pharmaceuticals. Novo Nordisk, after much introspection, incorporated its biopharmaceutical business (represented by the highly successful line NovoSeven ${ }^{\circledR}$ ) into its larger brand platform. In the sales of insulin in the United States, it is a major player; insulin sales surpassed Eli Lilly for the first time in 2006 in a rollercoaster competition. At the same time, as the company's marketing executives will point out, for Novo Nordisk, especially in some markets, a key moment of choice for corporate branding may come down to a few minutes a member of the sales force has with a physician. Will the salesperson stress product superiority or find time or a way to communicate corporate brand messages?

\section{ORIGINS OF THE NOVO WAY OF MANAGEMENT}

Nordisk Insulin Laboratorium was founded by August Krogh and Hans Christian Hagedorn and began manufacturing insulin in 1923. In 1925, two employees, Thorvald Pedersen and his brother Harald Pedersen, left Nordisk to start their own production of insulin under the company name Novo Terapeutisk Laboratorium. By the late 1980s, they had become the second- and third-largest insulin manufac- turers in the world. Eli Lilly was number one. Except genetically engineered insulin, almost all major innovations in insulin products were discovered in the laboratories of Novo or Nordisk. Novo has the broadest diabetes product portfolio in the industry. In 1989, Nordisk Gentofte and Novo merged into Novo Nordisk. The combined company re-organised into two business units-healthcare and enzymes. Yet by the second half of the 1990s, the rationale for keeping the businesses together became weaker. In 2000, Novo Nordisk and Novozymes began operating as two separately listed companies. Mads Øvlisen, Novo Nordisk's CEO, now chaired the board of the holding company Novo Nordisk A/S. Lars Rebien Sørensen, head of the former Healthcare division, became the new CEO of Nordisk Nordisk. Sørensen's goal was to take Novo Nordisk into the next century 'as the world's leading diabetes-care company with products and services in other areas where we can make a difference'. Partially as a result of differing regulatory issues in the US and EU insulin market, management decided to enhance empowerment throughout the company and require both increased accountability and willingness to share best practices within the global company.

This was called the "The Novo Nordisk Way of Management' (NNWoM), and was based on a set of guiding principles set out in 'The Charter.' The NNWoM increased emphasis on stakeholder values, CSR and environmental sustainability. These goals were implemented by dedicated global facilitators and sustainability reporting. Novo Nordisk became one of the first companies in the world to report on its resource consumption, emissions and use of experimental animals. The first official environmental report was published in 1994. In 1996, Novo Nordisk 
published its first report on social responsibility, which set targets and described the company's goals as a responsible corporate citizen. Environmental and social reporting was seen by top management as one of the most important methods for continued sustainable development. Since 2001, the company's performance has been measured by a TBL, which includes an evaluation of all company activities: social, environmental and economic. ${ }^{10}$ The company's relationship with stakeholders was further developed in a campaign called 'Being There'. This campaign emphasised engagement with medical practitioners, patients, employees and the wider global community through social responsibility—all as part of company philosophy.

'Being There' began with a campaign called 'I Wish'. Head of Corporate Communication Mike Rulis remembered: 'The I Wish campaign took the view of the patient we were there for. The campaign tells stories from real patients with real diseases ... by telling their story about their disease and their way of coping with it, they were indirectly telling the story about Novo Nordisk'. COO Kåre Schultz explains: 'We focused on the vision of the company, and on the corporate visual identity to make sure that the whole company looked the same worldwide'. But both Rulis and Schultz expressed doubts about the impact of the campaigns on the global brand. While they laid the foundation for a more unified corporate profile at a global level, they were viewed by many as inconsistent with corporate aspirations of being a global brand. Jesper Høiland, senior vice president of International Marketing, felt that 'the current platform is sporadic'. He saw, for example, initiatives in the United States that 'we have not benefited from globally. We have identified a number of the initiatives taken and asked ourselves, how can we, instead of having them stand alone make them stand together?'

Some significant steps would be taken before this could come to fruition. The first was an internal study by a team, the 'Brand Group' (BG), put together by Schultz and headed by Tina Nørgaard. The question at the time was whether the brand could be even more focused on diabetes, more differentiated in a portfolio industry. Novo Nordisk had by this time (2002) invested in a biotech venture started by a Swedish scientist. This venture led to the fast-growing success of the hemophilia drug NovoSeven ${ }^{\circledR}$. Danes seek consensus and avoid conflict. People from the diabetes wing of the company were concerned that the message of focusing more on diabetes would alienate colleagues working with NovoSeven ${ }^{\circledR}$. In Scandinavia, companies want everyone on board before moving to external corporate messages. Thus, the potential for de-motivating NovoSeven ${ }^{\circledR}$ employees was predominantly relevant in the Danish rather than the global context, particularly since production facilities are in Denmark. According to Nørgaard, the affiliates would be less affected by the level of prominence for NovoSeven ${ }^{\circledR}$ in the corporate branding efforts. NovoSeven ${ }^{\circledR}$ employees became enthusiastic about recommitting to diabetes as good for the company as a whole. In the fall of 2003, top management agreed that Novo Nordisk should be more customer-focused internally and externally, but the BG members split between wanting to emphasise the competitive spirit of Novo Nordisk and emphasising Novo Nordisk's achievements in corporate responsibility. These issues continue to resonate. For pragmatic Americans, what works tends to be the way to go. For Danes, there are tensions between being inclusive and the 
potential that a more focused brand may be more competitive. Ironically, the notion of an increased focus on internal stakeholders is just unfolding for many companies in the home of Coke and Nike, Starbucks and Ivory Soap.

\section{CHANGING DIABETES FROM COPENHAGEN TO NEW JERSEY}

In a key decision, managers in Copenhagen took notice of a campaign in North America in which a longer tag line included the phrase 'changing diabetes'. These words capture the spirit and values of the company's relationship to healthcare, values that had been realised, for example, in programmes such as DAWN ('Diabetes Attitudes Wishes and Needs') that married science to global philanthropy, and extended the companies' commitment to engage patients, scientists and NGOs. Novo Nordisk does not simply want to sell more of its products, it wants to bring patients under proper control (many people with diabetes do not receive the correct treatment), to raise awareness of Type 2's causes, to promote prevention and to change the treatment and lives of people with the disease. To coordinate the effort to align external and internal brand messages and values, Novo Nordisk brought in Charlotte Ersbøll. She works with a cross-functional brand team that is made up of high-level managers and works formally and informally with managers in Denmark in the areas of Global Talent Development, Marketing, R\&D, People and Organization, Corporate Communication and DAWN, as well as global subsidiaries. Corporate branding efforts have been moving forward on many fronts including a detailed brand strategy process, a highly segmented brand roadmap and a five-dimensional model to track brand goals. The company also uses the model of aligning vision, image and culture. ${ }^{11}$ At Novo Nordisk, brand also includes auditing whether the company is the world leader in diabetes care. Throughout the company, there is internal enthusiasm for the highprofile corporate branding effort. On a more general level, any corporate branding campaign is ultimately tested by its success in business terms. Until this is realised, there can remain in any company some doubt in the minds of functional managers: does successful branding really contribute to $\mathrm{R} \& \mathrm{D}$ ? Can it help the sales force? Will it be understood in the many cultures in which a global business operates?

From the outside, the corporate park and modern building of Novo Nordisk NA looks much like any other prosperous American corporate headquarters, except for the Danish and American flags standing side-by-side. This is in sharp contrast to the many small buildings in suburban Copenhagen that house Novo Nordisk NA. But once inside a visitor finds the same sparkling and sparse design, a bowl of fruit on a glass table and a long photo history chronicling the company's many inventions and patents. A flat screen plays a loop of company heritage and current activities. Certainly this 'brand space' suggests the continuity of corporate culture Novo Nordisk has worked so hard to nurture.

Novo Nordisk's North American President, Martin Soeters, is a native of the Netherlands, and has spent many years in both Denmark and the United States. Still, even from a European manager, it is bracing to hear, in Princeton, New Jersey, that a CEO feels the success of a company-and Novo Nordisk NA has been very successful-depends on 30 per cent people, 30 per cent brand and 40 per cent other factors. (This makes all the more sense in a company where many top managers are PhDs.) Andrew Purcell, 
Novo Nordisk's Vice President of marketing, a highly experienced pharmaceutical executive, made plain the connection between the argument for CSR and the business case for Novo Nordisk's new brand platform: 'changing diabetes' describes the 'virtuous circle' that comes from attracting and retaining the right people, the increased level of innovation and sense of purpose. Asked how Novo Nordisk finds employees who share the company's values, Purcell observes that he is willing to ask attractive candidates if Novo Nordisk is really the right place for them. Susan Jackson, the head of corporate communication at Novo Nordisk NA, works closely with the Danish corporate branding team. In terms of innovation, the line from culture to a brand that talented employees can connect to can be a fairly direct one. In 2006, Novo Nordisk became the leader in the US insulin market. The North American subsidiary accounted for 32 per cent of the company's total sales. Products like $\operatorname{NovoLog}^{\circledR}$ Mix 70/30, NovoLog, and LeveMir, and prefilled FlexPens helped differentiate the company and secure its position in traditional and modern insulin.

At the same time, the quest for an inhaled form of insulin, prematurely announced by Pfizer and leading to frontpage news, suggests how competitive this market is. The statistics on diabetes in the United States are staggering. The US Centers for Disease Control and Prevention estimates that one in three children born in the United States in 2000 will develop diabetes in their lifetime. The US healthcare system can hardly address the problem of diabetes adequately, with too few diabetes specialists, too little training in diabetes among primary care physicians, too little awareness of the diagnosis and treatment of diabetes among the general public and too little awareness among policymakers of the seriousness of diabetes. To prevent this daunting future, Novo Nordisk wishes to change diabetes.

Through 'The Novo Way of Management' and 'Changing Diabetes' Novo Nordisk has made the crucial investment in 'internal' branding, taking core brand messages to global subsidiaries, with extensive workshops and global brand strategy development. The company's philosophy is exemplified by the fact that each employee worldwide spends a day with a patient. Too many companies still feel branding is about messages, not actions, about external audiences, not employees. Soon after establishing a recommitment to diabetes, managers felt that this in itself was an insufficient platform for the alignment of internal and external branding, yet the process led to the conceptualization of the brand in terms of "changing diabetes'. It is a brand platform that expresses the company's cultural identity and goals, and is expansive and inclusive. It has institutionalised a commitment to corporate branding, with a manager at the level of Vice President. Still, in trying to understand the future of Novo Nordisk's brand translation, cultural context plays a large role. Will Danish managers in Copenhagen grasp the extent to which Nordic business' relationships to stakeholders are far from self-evident to financially oriented American managers? Will they understand a US public that has been told for many years that the only solution is a market solution, or customers who make choices on price first, and factors such as CSR second? This is not necessarily a problem, if Europeans understand the extent to which, for many Americans, investment in corporate branding tied to CSR in public companies is often a result of a crisis, seen as necessary risk management, or if profits and sales allow justifying the 'extra' cost, a luxury. 
In America, categories such as profit, market share and share price on the one hand, and TBL reporting, a commitment to employees, and environmental and social responsibility, on the other, remain in an uneasy coexistence. More generally, the nurturing of a sustainable global corporate brand, if current trends in worldwide public opinion continue, will require a way to balance all of the above. Of course, J\&J, by performing so well in reputation polls, is the one exception among American pharmaceuticals. Its core associations of corporate values with 'mothers, babies, and band aids', remains intact and is refreshed through campaigns like 'having a baby changes everything'. To be sure, J\&J's consumer products are dwarfed by its pharmaceutical business. Yet, its fidelity to its famous credo that puts healthcare workers and employees in the number one and two spots adds real substance to its high standing, as does such philanthropy as J\&J's 'Campaign for Nurses', a direct extension of its credo's stakeholder commitment. J\&J thinks of a brand in terms of 'corporate equity', meaning neither brand nor stakeholders are separate from 'business'. This illustrates a point R. Edward Freeman has argued since 1994, regarding the fallacy of 'separation theory', that is, the fallacy and harm of seeing 'the business' as separate from its stakeholders. ${ }^{12-14}$ Properly conceived, a brand may reconnect this separation, emotionally as well as through action.

Novo Nordisk's success in North America suggests it has connected with key stakeholders in the global healthcare and scientific community and sees its business as inseparable from its stakeholders. Its support of American National Public Radio, which comes with the announcement that 'diabetes is our passion, not just our business', reaches an important demographic and sets the stage for the more complex message of 'Changing Diabetes'. Does Novo Nordisk need wider public awareness among a larger set of stakeholders? In some ways, perhaps not, but general public perception affects targeted stakeholders and there is certainly an opportunity. The opportunity is made tangible by the work of the first internal brand team and the current work of the brand team coordinated by Ersbøll. So too, the willingness of Copenhagen to see the potential of a brand platform articulated by a subsidiary says much about the company's collaborative culture. Enlightened managers with global experience like Soeters are a cause for optimism in managing global differences. Novo Nordisk NA is well positioned for its tangible challenge of competing on innovation. Products like the Novo Pen should become more widely known as, sadly, the Type 2 epidemic continues to grow. In keeping with Nordic aesthetics, the pens are attractively designed. In keeping with Novo Nordisk's ethos, they also make life with Type 1 diabetes much simpler, for example, for a school-age child. Novo Nordisk's products can change a life in many ways.

\section{CONCLUSION}

What are the lessons for Nordic brands in the United States? It is telling that David Aaker made the case for 'leveraging' corporate brands, with caveats, as recently as $2004 .{ }^{15}$ This opened the way for more academic discussion of corporate branding, yet it is also telling because the case still had to be made in a strategy journal so recently. Simply put, for Americans, product brands lend themselves more readily to measurement, and corporate brands are, in contrast to Scandinavia, still moving conceptually from the intangible to the indispensable. Americans have long 
admired and lived with Nordic brands. Saab and Volvo evolved from eccentric 'practical' cars to luxury brands. Absolut famously has one of the most admired and flexible advertising campaigns in history. Dansk and Bang and Olufson have long been known for superior design-even if this is something of a cliché. The point here, however, is that these are luxury or differentiated brands. ${ }^{16}$ Novo Nordisk is differentiated, but it is hardly a luxury. Still, Novo Nordisk's delivery devices have the attractiveness of Scandinavian design, and if this helps more people to bring their diabetes under control, so much the better.

In recent years, Korea's Samsung has made large gains in the design space in the consumer electronics market. Yet, Samsung has rebranded from emphasising design to 'connecting' people. It is not what the product looks like, but what it does. This becomes even more resonant if one thinks of Indian or Swedish advertising, which emphasise family and group occasions. The pharmaceutical lobby in the United States tends to spend too much time defending why it needs 17 per cent ROI to maintain its R\&D. Here 'changing diabetes' is far ahead of the curve. It captures the goals of a healthcare company whose values are badly needed in the American as well as the global market and a brand promise worth aspiring to. Ironically, the United States seems to be in denial about both its diabetes epidemic and its healthcare crisis as it waits for the free market to solve these problems through an invisible hand-a phenomenon that could well affect Novo Nordisk's general brand awareness. Yet the future of companies that combine innovation with CSR seems to be in how well aligned these commitments are with corporate strategy and identity, and here Novo Nordisk has the advantage. If Americans want the market to solve large problems like the diabetes crisis, Novo Nordisk is a brand whose Nordic stakeholder values may make this possible.

More generally, we argue that even in specialised markets like the pharmaceutical industry, engaging as many stakeholders as possible is beneficial and at times necessary. The notions of goodwill in a crisis and intangible effect on stock price are well known. ${ }^{17}$ In Pattern Recognition, William Gibson's 'science fiction' book set in the present, the heroine, an American brand savant, calls London the 'mirror world'. ${ }^{18}$ England is like the United States but it is not, and this notion is all the more true of Scandinavia. Managers of Scandinavian companies must come to terms with how entranced by free market economic theories the United States has become since the 1970s. They may be emphasising the 'business case' for CSR for some time. Globalisation, ironically, seemed to end all arguments that any other options were available. Yet, there is a larger reason for Nordic brands to connect with as many American stakeholders as possible. The cost of not investing in employees becomes more and more apparent. Public opinion has been moving towards increased awareness of environmental and social concerns and towards companies that balance these concerns with their business goals. In short, the trump card of public opinion and public needs has been moving towards Nordic brand values.

\section{References and Notes}

(1) Novo Nordisk Annual Review, 2005.

(2) See Schultz, M. Rubin, J. and Hatch, M. J., Novo Nordisk: Focusing the Corporate Brand'. Darden Publishing, University of Virginia, (UVA-BC192) 2004. See also the forthcoming case by the same authors on Novo Nordisk and Corporate Branding. These cases are published by Darden but are co-branded by Copenhagen Business School, Darden, and the McIntire of Commerce 
at the University of Virginia. See also 'Nissan: Renewing the Corporate Brand', (UVA-BC194) by Rubin, J., Hatch, M. J. and Schultz, M.

(3) Quotations and data on Novo Nordisk come from Novo Nordisk publications or interviews with managers in Copenhagen and Princeton, New Jersey unless otherwise noted.

(4) For as one of many examples, Schultz, M. M. Hatch, M. J. and Larsen, M. H, (eds) (2000) 'The Expressive Organization: Linking Identity, Reputation, and The Corporate Brand', Oxford University Press, as well as Ind, N. (1997) 'The Corporate Brand', New York University Press, New York. Nicholas Ind. (2001) 'Living the Brand', Kogan Page, London. Olins, W. (2003) ‘On Brand', Thames and Hudson, London.

(5) The Corporate Brand Initiative was a three-year learning network among corporate brand managers from the Lego group, Nissan, Novo Nordisk, Johnson \& Johnson, ING Group, Telefonica, SONY and Boeing. It was started by Majken Schultz and Mary Jo Hatch and funded by the Lego Group, Copenhagen Business School and the Danish Research Council. It involved regular meetings held on both sides of the Atlantic and focused on defining and refining the field of brand management by sharing issues and challenges as they developed over the course of the CBI.

(6) This crisis was set off by a highly problematic set of articles published in the San Francisco Chronicle.

(7) Olins, W. (1989) 'The Search for Corporate Identity: Making Business Strategy Visible through Design', Harvard Business School Press, Cambridge.

(8) Balmer, J. M. T. and Greyser, S., (eds) (2003) 'Revealing the Corporation', Routledge, London and New York.
(9) See the Domini 400 Social Index, The Calvert Social Index, The Dow Jones Sustainability Index and the FTSE4Good.

(10) Morsing, M. and Oswald, D. (2004) 'Novo Nordisk A/S/-Integrating sustainability into business practice', in Kakabadse and Morsing (eds) 'Corporate Social Responsibility: Reconciling Aspiration with Application', Palgrave, London.

(11) See Hatch, M. J. and Schultz, M. Are the strategic stars aligned for your corporate brand?', Harvard Business Review, February, 2001, for a specific example of model. Books and articles by these authors on brand are too numerous to mention.

(12) Freeman, R. E. (1994) 'The politics of stakeholder theory', Business Ethics Quarterly, pp. 409422.

(13) Harris, J. and Soulder, D. Bad apples or bad Bushel? Ethics, efficiency and capital market integrity', Business and Professional Ethics Journal, Vol. 23, No. 1, pp. 201-222.

(14) Freeman, R. E., Harrison, J. S. and Wicks, A. (2007) 'Managing for Stakeholders: Survival, Reputation, and Success', Yale University Press, New Haven.

(15) Aaker, D. A. (2004) 'Leveraging the corporate brand', California Management Review, Vol. 46, No. 3, pp. 6-18.

(16) Dru, J. M. (1997) 'Disruption: Overturning Conventions and Shaking up the Marketplace', John Wiley \& Sons, and Beyond Disruption: Changing the Rules in the Marketplace. John Wiley and Sons, 2002.

(17) Fombrun, C. (1996) 'Realizing Value from the Corporate Image', Harvard Business School Press, Cambridge.

(18) Gibson,W. (2003) 'Pattern Recognition', Putnam, New York. 